\title{
Government Funding NIH Institute Code
}

National Cancer Institute

\section{Source}

National Cancer Institute. Government Funding NIH Institute Code. NCI Thesaurus. Code C93839.

A two letter coded value specifying the first major-level subdivision of the org anization that supports a grant, contract, or inter-agency agreement. The support may be financial or administrative. 